\title{
Macroscopic study of syrinx in the common bulbul (Pycnontus barbatus) and indigenous pigeon (Columba domestica)
}

\author{
A. M.S.AL-badri \\ Coll. of sci. Univ. of \\ Wasit
}

\author{
B. A. Jassim \\ Coll. of sci./ Univ. of \\ Al- Muthana
}

\author{
J. G. Abbas \\ Coll. of Vet. Med./ Univ. of \\ Al- Qassim green
}

In this study, syrinx of five male common bulbuls (Pycnontus barbatus) weighing $(25.93 \pm 0.89 \mathrm{~g})$ and five male indigenous pigeons (Columba domestica) weighing (286 \pm 0.73 g) were examined for macroscopic structure. The results showed the anatomical positions of the syrinx. The syrinx was observed ventral to the esophagus exactly on the base of heart in the common bulbul, whilst in pigeon; the syrinx was hidden by the heart. The morphological structure of the syrinx in both species could be classified as tracheobronchial type. The number of tracheo-syringeal rings could not be determined certainly in common bulbul, while in the pigeon, tracheo-syringeal part was composed of the two cartilaginous rings (T1 and T2). These two cartilaginous rings were different in diameters, and joined each other at middle. In the common bulbul, tympanum which is the middle part of syrinx has the bilateral bulla; while tympanum of pigeon does not have bulla. Furthermore the broncheo-syringeal cartilages form the caudal part of syrinx, which are composed of five $\mathrm{C}$-shaped rings in both species. The caudal syringeal part of common bulbul has interbronchial foramen, which absents in pigeon.

Key words : Macroscopic, Syrinx, Common Bulbul, Pigeon.

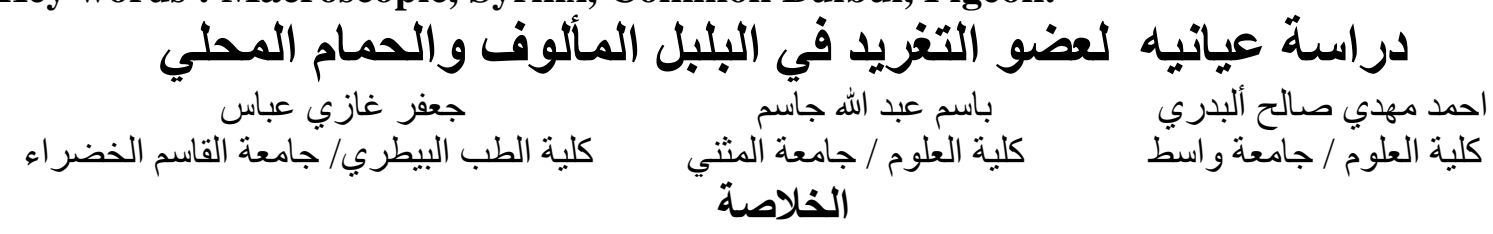

في هذه الدراسة, تم فحص التركيب العياني لعضو التغريد لخمسة من ذكور البلبل المألوف والذي يزن 2 التون

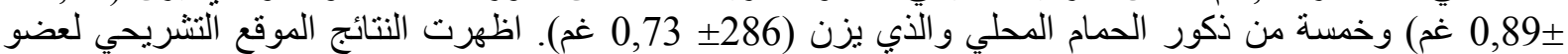

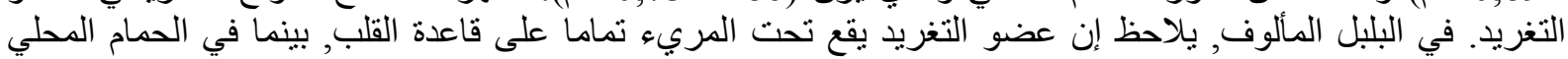

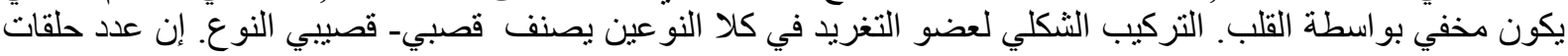

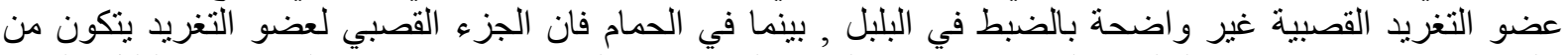

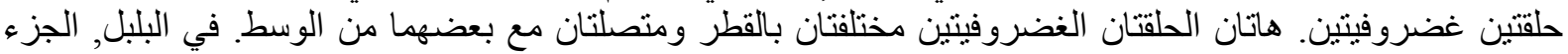

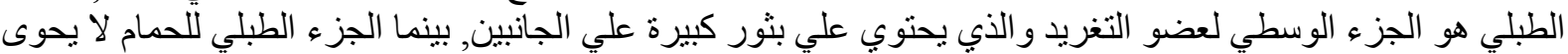

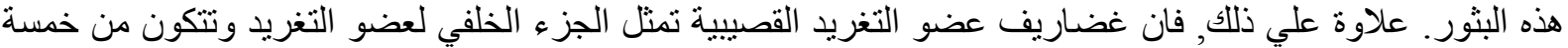

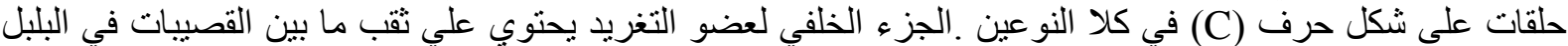
المألوف, و الذي يكون مفقود بات بالحمام. الكلمات المفتاحية: البلبل، الحمام، عضو التغريد.

\section{Introduction}

The major functions of the avian respiratory system are oxygen and carbon dioxide exchange, balance of body temperature and contribution to sound production. Air inspired during respiration passes from the nasal cavity to the larynx and continues via the trachea and enters the syrinx and bronchi (1-4) .Some birds vocalize all year long while others call only during the mating season or during migration
(5). In birds the voice producing apparatus is located in the thoracic cavity, so that the body cavity filled numerous air sacs, represents a giant resonant organ such as no other animals possess. The voice organ of the birds, the syrinx, is located at the bifurcation of the trachea (6). Its detailed structure is exceedingly variable among the avian species. Regarding to cartilages derivation in embryonic stages in different groups of birds, syrinx has been classified 
into tracheobronchial, tracheal and bronchial types $(7,8)$.Last portion of trachea or beginning of bronchus, or both (especially in domestic chicken) participate in the formation of the syrinx $(9,10,11,12,13$, 14) . Thus, the syrinx is classified as tracheobronchial, bronchial and tracheal $(2,15,16,17)$. Two membranes in the syrinx, the membrane tympani forms lateral and medial produce sound $(2,18,19)$. These membranes are activated by the intrinsic and extrinsic muscles (18) . Birds that vocalize possess both the intrinsic and extrinsic syringeal muscles. There is much variations among species $(20,21,22)$, the vast majority of non-singing birds possess sternotrachealis muscle and tracheolateralis muscle which are extrinsic syringeal muscles $(16,23)$ .Larynx, trachea and syrinx have been morphologically and physiologically studied in numerous species of birds $(19,19,24)$. As well as the role of these structures in vocalization (25) and neuromuscular control of voice and function of syringeal muscles(18) have been investigated in syrinx of many types of birds. Sexual dimorphism was observed in mallards and its differences were investigated in detail (12).To date, the anatomical structure of pigeon and common bulbul (song bird) have not been described in detail. On other hand, the syrinx represents one of the smallest biological sound sources, which is used to produce extremely loud and complex vocalizations. Therefore, the determination of the structure of syrinx in these species is the aims of the present study.

\section{Materials and methods}

Five male (one-year) common bulbuls $(25.93 \pm 0.89$ gram $)$ and five males pigeons weighing $286 \pm 0.73$ gram were collected from a local commercial market of birds in Al-kut city. The body cavity had been opened, in order to investigate the topographical position of syrinx within all the birds. Syrinx of pigeon had been taken out of body cavity by cutting in $1 \mathrm{~cm}$ distance above and down the syrinx .Whilst the cutting was 0.5 distances above and down the syrinx in common bulbul. These birds were previously fed over a period of two weeks before using to confirm that all studied birds were free of any clinical abnormality or lesions.

\section{Results and discussion}

Both species (pigeon and common bulbul) showed that syrinx located between the last portion of the trachea and the first part of the left and right primary bronchi. However the anatomical positions of the syrinx were different in both species. The syrinx was observed in ventral of the esophagus, which was exactly on the base of heart in the common bulbul (figure 1). While the pigeon, syrinx located in the thorax, which was hidden by the heart (figure 2). The topographical findings of the syrinx in pigeon and common bulbul were similar to those of the chicken, rooster, turkey, ostrich and long-legged buzzard $(11,23,26,27)$.The skeletal structure of the syrinx was composed of 3 different cartilage groups: tracheo-syringeal cartilage, tympanum (intermediate cartilage) and broncho-syringeal cartilage in both species. The morphological structure of the syrinx has been described in many bird species ( $8,22,27)$. Since both the trachea and primary bronchus participated in formation of the pigeon and common bulbul syrinx, which could be classified as trachea bronchial type comparable to chickens, ostrich, male mallard and long-legged buzzard groups $(4,8,12,23,26)$.In male common bulbul (songbird), the borders of first five cartilage rings of the tracheo-syringeal cartilage were separate. However, the other rings' borders of the tracheo-syringeal cartilage completely fused to form the tympanum (figure 3). Therefore, the findings that was obtained from the present study revealed different out comes from the result of (16). While the number of the tracheal rings forming of the tympanum were reported as 3-4 in the domestic chicken (3), 4 in the Denizli rooster (28), 3 in the long legged buzzard, and 5 in ostrich (26). The number of tracheosyringeal rings could not be determined certainly in common bulbul. However, the extensively modified in bulbul tympanum has bilaterally asymmetrical dilation form called the syrinx bulla (figure 3).On other 
hand, the dorsoventral (DV) length of bulbul tympanum is larger than craniocaudal (CC) length (Table 1). This finding agree with (2) work on Dendrocygnini (a species of whistling duck that breeds in the Southeast Asia). While the researchers mentioned in the shelducks (group of larger often semiterrestrial waterfowl), the bulla occurs on the right side of the syrinx (2). We suggested that bilaterally asymmetrical dilation present in birds, which produce their complex and continuous vocalizations are similar to common bulbul. Whereas (29) have demonstrated that whistling duck usually produce a repetitive wheezy call. The anatomical result from dissecting microscopy study showed that the broncho-syringeal cartilage were look like $\mathrm{C}$-shaped in common bulbul. Furthermore data showed there were (5) $c$-shape on each side. The medial tympani form membranes (MTM) are connected to the rostral end of each broncho-syringeal cartilaginous ring. The interbronchial foramen was bordered by the tympanum cranially, the medial tympani form membranes and connective tissue caudally. Both latero-lateral and dorso-ventral decreased in size from cranially to caudally when connect with primary bronchi. (figure 4). Although C-shaped cartilage rings, which compose the bronchosyringeal part of syrinx were reported to be formed by only the first cartilage ring in the turkey (29), the first three cartilage rings in domestic fowls $(4,8)$ and Japanese quail $(24)$, the first four cartilage rings in long legged buzzard (23) and crow (9), and the first six cartilage rings in goose (31). the broncho-syringeal cartilage part of syrinx in common bulbul was formed by the first five cartilages in songbird of the present study. Nevertheless, common bulbul has 5 broncho-syringeal cartilage rings, which give the ability of whishing. In other words, more cartilage rings mean more ability to sing and whistle. The interbronchial foramen, which helps the medial tympani form membranes (MTM) to vibrate and produce sound, was observed in the common bulbul as reported in goose and some singing birds $(4,31)$.In the pigeon, the syrinx is composed of the two tracheo-syringeal cartilaginous rings ( $\mathrm{T} 1$ and T2) and the five semi-rings of the bronchosyringeal cartilages (figure 5). Similar data has been documented in Columbidae by other scientists $(22,25)$. The diameter of $\mathrm{T} 1$ is larger than T2 (table 1) and both these trachea-syryngial cartilages are enlarged and thickened ventrally. Moreover, they are not fully closed on the dorsal side. Whilst the ventral end of $\mathrm{T} 1$ is partially fused with dorsal end of T2 at middle (figure 4). Our result has been supported by other evidence, which were described in pigeon and in male and female goose. The tracheo-syringeal cartilages were composed of two cartilagous rings (31,32). The lateral tympani form membranes (LTM) extend over the lateral and dorsal area between TI and T2. The medial tympani form membranes (MTM) are situated on the medial sides of the rostral end of each bronchus (5). There was no tympanic bulla in the pigeon's syrinx. Morphological characteristics that were pertaining to the present study were confirmed with that has been described previously in the syrinx of pigeons (22).The sound is generally thought to be generated by alternating compression and rarefaction of air as the membranes move into and out of the syringeal lumen (33). This classical model of avian phonation is one of main physical mechanisms of sound (34). Whereas (25) have confirmed that the main role of the LTM as soundgenerating structures and the MTM were not the primary sound generators in pigeon. Result showed that $\mathrm{T} 1$ and $\mathrm{T} 2$ jointed each other (figure 5), instigating to restrict in LTM vibration. The latter could leading to decrease in capability of producing continuous sound. On other hand, this observation disagree with other who noted the trachio-syringeal cartilages were composed of 2 cartilaginous rings, the ventral and dorsal ends of intermediate cartilage were not joined each other in turkey (35). The broncheo-syringeal cartilages were composed of five $\mathrm{C}$-shaped rings. This caudal syringeal part does not have interbronchial foramen that observed in the common bulbul. Anatomical observation of the present work was not similar to the previously observation in turkey (30), in Japanese quail (24), and in goose (31), which these differences can be completely or partially associated with species variation in birds. explained by species variation detected in birds. 
(Table 1): Illustrated body weight for two species, dorsoventral (DV) and craniocaudal (CC) length of tympanum for bulbul and diameters of tracheo-syringeal rings (T1,T2) of pigeons syrinx.

\begin{tabular}{|c|c|c|c|c|c|}
\hline \multicolumn{2}{|c|}{ Body weight / g } & \multicolumn{2}{|c|}{$\begin{array}{c}\text { The (DV) and (CC) lengths of } \\
\text { tympanum for bulbul / } \mathrm{mm}\end{array}$} & \multicolumn{2}{c|}{$\begin{array}{c}\text { The diameters of (T1,T2) of } \\
\text { pigeons syrinx / mm. }\end{array}$} \\
\hline Pigeon & Bulbul & DV & CC & T1 & T2 \\
\hline $286 \pm 0.73$ & $25.93 \pm 0.89$ & $7.52 \pm 0.17 \mathrm{~A}$ & $5.81 \pm 0.11 \mathrm{~B}$ & $5.17 \pm 0.22 \mathrm{~A}$ & $4.16 \pm 0.06 \mathrm{~B}$ \\
\hline
\end{tabular}

Values are mean \pm SE.

Note: The data with different capital letters show significant differences.

(Table 2): Illustrated many abbreviations.

\begin{tabular}{|c|c|c|}
\hline 1 & T1 & First tracheo-syringeal cartilaginous ring \\
\hline 2 & T2 & Second tracheo-syringeal cartilaginous ring \\
\hline 3 & LTM & Lateral tympaniform membrane \\
\hline 4 & MTM & Medial tympaniform membrane \\
\hline
\end{tabular}

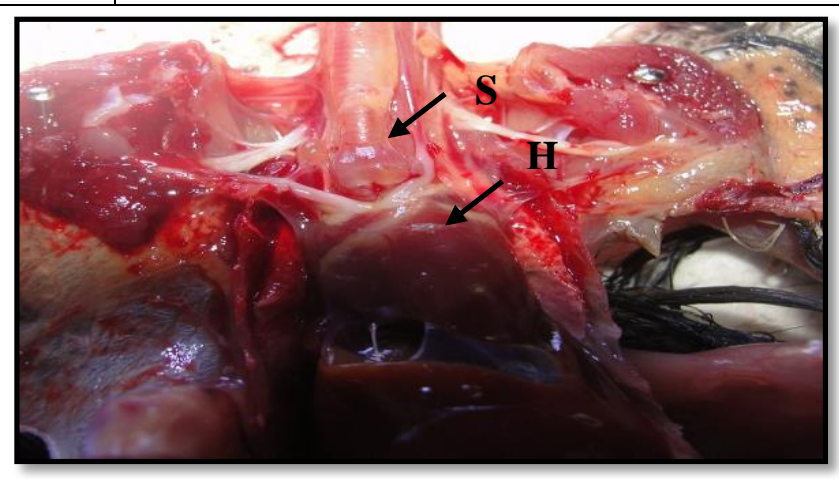

(Fig. 1): Ventral view of thoracic cavity in the male common bulbul. The syrinx (S) observed exactly on the base of heart $(\mathrm{H})$.

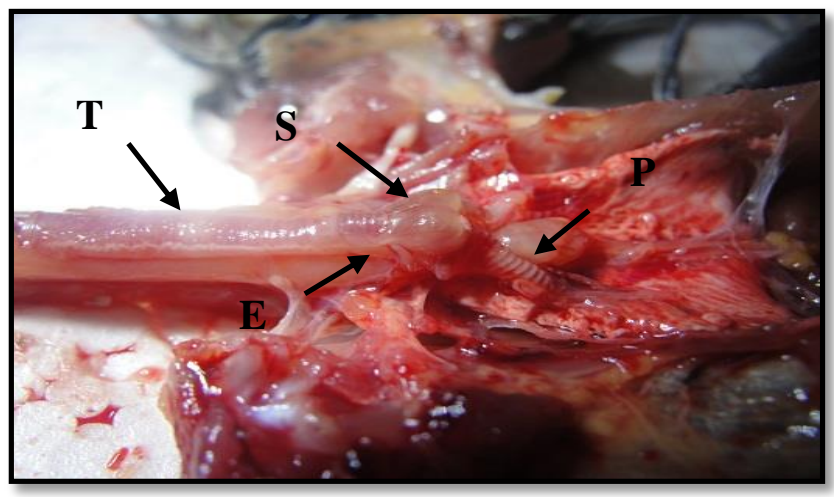

(Fig.2): Ventral view of thoracic cavity in the male common bulbul. The syrinx (S) observed ventral to the esophagus (E). Trachea (T), Primary bronchia $(\mathrm{P})$.

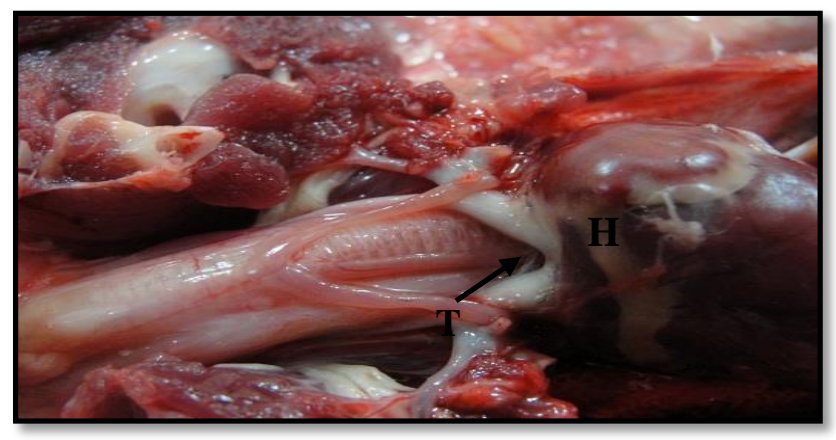

(Fig. 3): Ventral view of thoracic cavity in the male pigeon. The syrinx observed is hidden at the dorsal surface of the heart $(\mathrm{H})$ and only tracheal end $(\mathrm{T})$ which appear. 


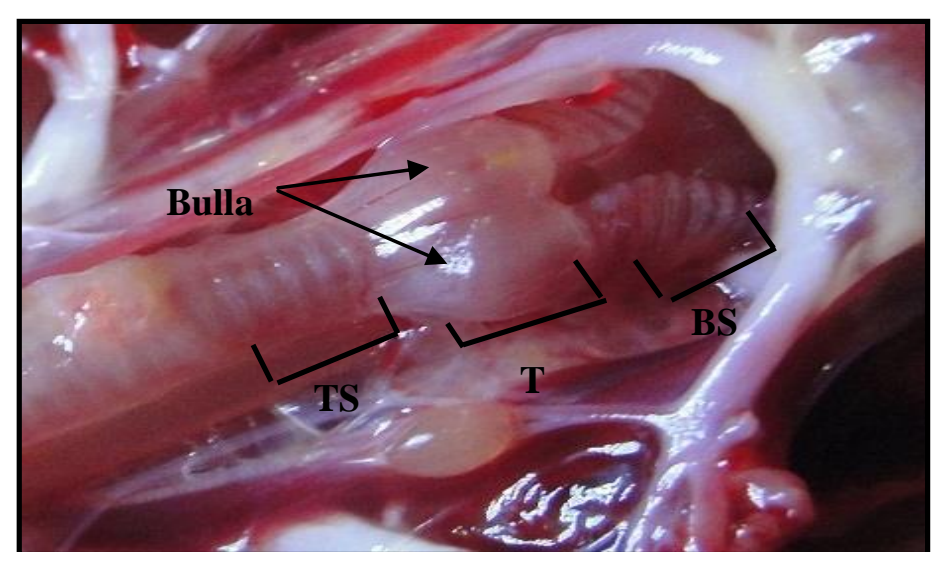

(fig. 4): Ventral view of common bulbul syrinx showing the tracheo-syringeal cartilaginous rings (TS), tympanum (bilaterally bulla) (T), and the broncho-syringeal (BS) part of syrinx

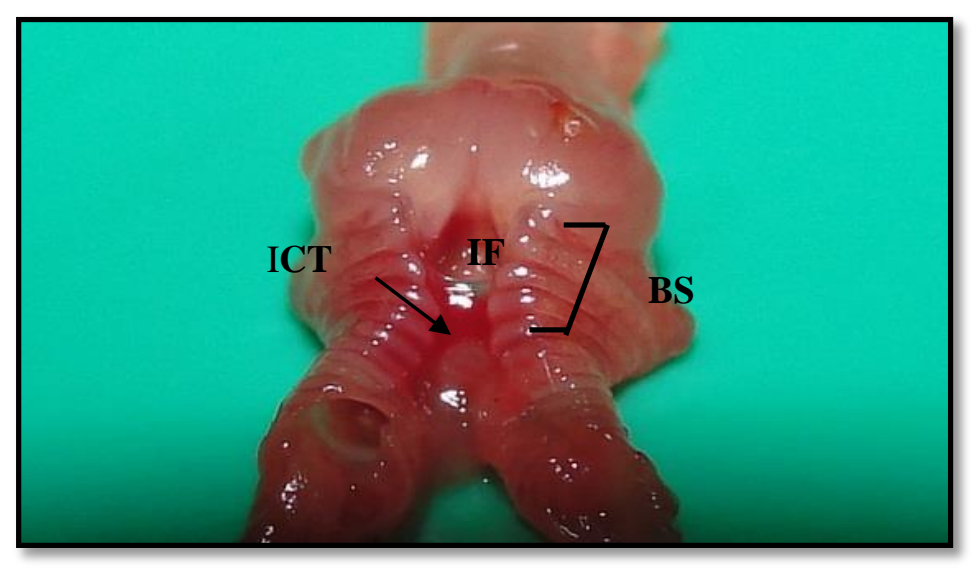

(fig. 5): Ventral view of common bulbul syrinx showing the five broncho-syringeal (BS) rigs on each side, the interbronchiale foramen (IF) and interchiale connective tissue (ICT).

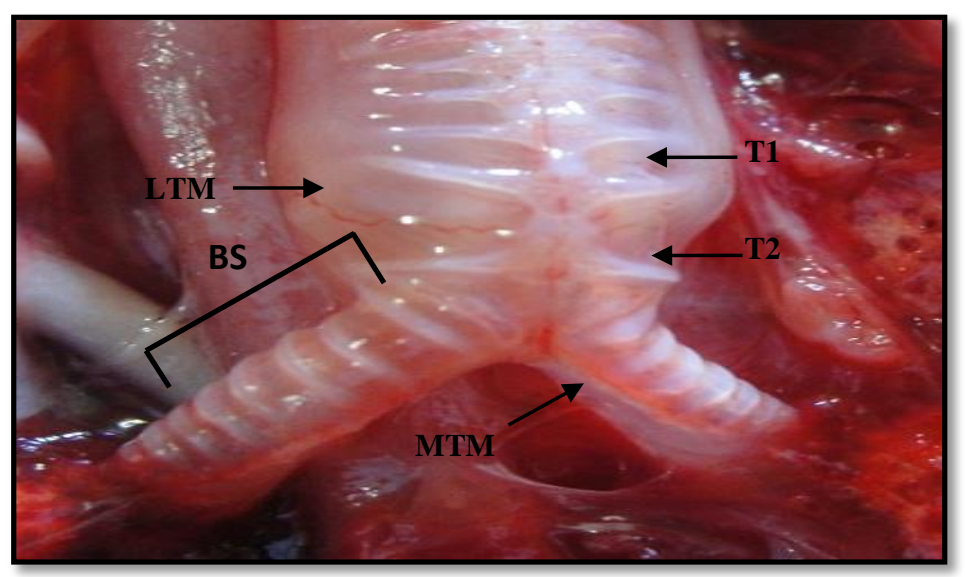

(Fig. 6): Ventral view of pigeon syrinx showing two tracheo-syringeal rings (T1,T2), the bronchosyringeal rings (BS), the lateral (LTM) and medial (MTM) tympaniform membranes 


\section{References}

1.Fedde, M.R. (1998). Relationship of structure and function of the avian respiratory system to disease susceptibility. Poult Sci. 77: 1130-1138.

2.King, AS. and McLelland, J. (1984). Birds: Their Structure and Function. 2nd edn. pp. Bailliere ,Tindall, London. 110-144.

3.Getty, R.(1975). The Anatomy of the Domestic Animals Vol 2.5th edition, W.B.Saunders Company. pp: 1896-1902.

4.Nickel, R. ; Schummer , A. and Seiferle, E. (1977). Anatomy of the Domestic Birds. Verlag Paul Parey, Hamburg. pp. 65-70.

5. Demirsoy, A. (1992). Yaşamnn Temel Kurallarn. Meteksan Publisher, Ankara, pp. 287-300.

6.Koch, T., (1973). Anatomy of the Chicken and.Domestic Birds. 1st edition, The Iowa State University Press Ames, Iowa, pp: 84-88.

7.Hodges, R.D., (1974). The Histology of the Fowl. 1st edition,AcademicPress London, pp: 126-131.

8.King, A.S. and Mclellan, J. (1975). Outlines of Avian Anatomy, 1st edition, Bailiere and Tindall, London, pp: 47-51.

9.Chamberlain, D.R.;Gross ,W.B.; Cornwell, G.W and Mosby H.S.(1968). Syringeal anatomy in the common crow. The Auk. 85: 244-252.

10. Doğuer, S. and Erençin, Z.(1964). Evcil Kuşlarnn Komparatif Anatomisi. Ankara University Press, Ankara. pp. 49-50

11.Dyce, K.M.; Sack, W.O. and Wensing, C.J. (2002). Textbook ofVeterinary Anatomy. 2nd ed.W.B Saunders Co., Philadelphia. pp. 812-815.

12.Frank, T.; Probst, A.; König, H.E. and Walter, I.(2007).The syrinx of the Male Mallard (Anas Platyrhynchos) special anatomical features. Anat. Histol. Embryol. 36: 121-126.

13. King, A.S(1989). Functional Anatomy of the Syrinx. In: Form and Function in Birds. Academic Press, London. pp. 105-182.

14.Seller, T.J.(1987).Bird Respiration. Vol. I. CRC Press, USA. pp. 72-75.

15.Öcal, K. and Erden, H.(2002) Solunum sistemi. Evcil Kuşlarnn Anatomisi. pp. 91-102. Medisan Publisher, Ankara, 2002.

16.Baumel, J.J.; King, A.S.; Breazile, J.E.; Evans, H.E. and Vanden Berge, J.C.(1993) Nomina Anatomica Avium. 2nd ed. .MA Nuttall Ornithological Club, Cambridge. Pp: 327

17. Demirsoy, A.(1992).Yaşamnn Temel Kurallarn. Meteksan Publisher, Ankara. Pp:287-300.

18.Goller, F. and Suthers, R.A.(1996).Role of syringeal muscles in gating airflow and sound production in singing brown thrashers. $\mathrm{J}$. Neurophysiol. 75: 867-876.

19.Griffiths, C.S.(1994). Monophyly of the Falconiformes based on syringeal morphology. The Auk. 111: 787-805.
20.Seller, T.J.(1987). Bird Respiration. Vol. I. CRC Press, USA, pp. 72-75.

21.Bell, D.J. and Freeman, B.M. (1971). Phisyology and Biochemistry of the Domestic Fowl. UK Academic Press, London. pp. 100-101.

22. Warner, R. W. (1972). The syrinx in family Columbidae. J. Zool., Lond. 166: 385-390.

23.Kabak, M.; Haziroğlu, R.M. and Orhan, I.O.(2007). The gross anatomy of larynx, trachea and syrinx in the Long-Legged Buzzard (Buteo rufinus). Anat. Histol. Embryol. 36: 27-32.

24.Çevik-Demirkan, A. Haziroğlu, R.M, and Kürtül, I.(2007) Gross morphological and histological features of larynx, trachea and syrinx in Japanese quail. Anat. Histol. Embryol. 36: 215-219.

25.Goller, F.and Larsen, O.N.(1997). In situ biomechanics of the syrinx and sound generation in pigeons. J. Exp. Biol.200: 2165-2176.

26.Yildiz, H.; Bahadir, A. and Akkoç, A.(2003) A study on the morphological structure of syrinx in ostriches (Struthio camelus). Anat Histo.1 Embryol., 32: 187-191.

27.Bettina, M. and Pablo,L.T. (2001). Relationship between song characters and morphology in new world turkeys. Bio. J. Linn Soc., 74: 533-539.

28.Taşbaş, M. ; Haziroğlu, R.M.; Çakir, A. and Özer, M.(1994) Denizli horozunun solunum sisteminin morfolojisi. II. Larynx, trachea, syrinx.. 41: 135153.

29.Rasmussen, P.C. \& Anderton, J.C. (2005). Birds of South Asia. The Ripley Guide. Washington DC and Barcelona: Smithsonian Institution and Lynx Edicions. Vol. 2: p. 68.

30.Cover, M.S.(1953). Cross and microscopic anatomy of the respiratory system of the turkey. II. Larynx, trachea, syrinx, bronchi and lungs. Am. J. Vet. Res. 14: 230-238.

31.Onuk, B. ; Haziroglu, R.M . and Kabak, M. (2010). The Gross Anatomy of Larynx, Trachae and Syrinx in Goose (Anser anser domesticus). Kafkas Univ Vet Fak Derg .16 (3): 443-450.

32.Abs, M. (1980). Zur Bioakustik des Stimmbruchs bei Vögeln. Zool. Jb. Physiol. 84, 289-382.

33.Stein, R. C. (1968). Modulation in bird sounds. Auk .85: 229-243.

34.Fletcher, N. H. (1989). Acoustics of bird song some unresolved problems. Comments Theor. Biol. 4: 237-251.

35.Khaksar,Z.; Tavakol Kookhdan ,E. and Parto, P. (2012). A Study on Anatomy and Histological Structure of Larynx in Adult Male and Female Turkeys. World Journal of Zoology. 7 (3): 245 250. 